九州大学学術情報リポジトリ

Kyushu University Institutional Repository

\title{
Study on Desiccant Dehumidification System Using Experiments and Steady-State Model
}

Ishaq, Muhammad

Department of Agricultural Engineering, Bahauddin Zakariya University

Aleem, Muhammad

Department of Agricultural Engineering, Bahauddin Zakariya University

Ashraf, Hadeed

Department of Agricultural Engineering, Bahauddin Zakariya University

Hafiz S. Ullah

Department of Agricultural Engineering, Bahauddin Zakariya University

他

https://doi.org/10.5109/4102471

出版情報: Proceedings of International Exchange and Innovation Conference on Engineering \& Sciences (IEICES). 6, pp.92-97，2020-10-22. 九州大学大学院総合理工学府 バージョン:

権利関係: 


\title{
Study on Desiccant Dehumidification System Using Experiments and Steady-State Model
}

\author{
Muhammad Ishaq ${ }^{1}$, Muhammad Aleem ${ }^{1}$, Hadeed Ashraf ${ }^{1}$, Hafiz S. Ullah ${ }^{1}$, Muhammad Sultan ${ }^{1, *}$ \\ ${ }^{1}$ Department of Agricultural Engineering, Bahauddin Zakariya University, Multan 60800, Pakistan \\ Corresponding author email: muhammadsultan@bzu.edu.pk
}

\begin{abstract}
Recently, desiccant air conditioning system is an alternative to conventional air-conditioning system in effective control of temperature and humidity. Temperature and humidity play an important role in the thermal comfort of humans. In the agriculture sector, it can be used to reduce post-harvest losses by providing specific conditions of about temperature and humidity in the storage system. Working principle of the DAC system is shown in the schematic diagram with a representation of the psychrometric chart. DAC system is water adsorption system as it adsorbs water and dehumidifies the air required for a specific purpose. DAC contains silica gel with different configurations. Air is passed through the DAC system and dehumidified after being released. Some analysis is made under controlled conditions and feasibility of the system is checked by applying Beccali Model available in the literature. Results show that DAC system is more economical and energy-saving with environment-friendly characteristics. DAC system is applicable in all conditions of agriculture products storage and industrial-scale air conditioning.
\end{abstract}

Keywords: Desiccant dehumidification air conditioning, feasibility

\section{INTRODUCTION}

Air Conditioning is a procedure of controlling the humidity and temperature of an air in a specific environment. Different climatic areas have different types of requirements regarding air conditioning for humid dry and hot conditions. But that system should be environment friendly, cheap and energy efficient [1].

In modern human life, primary energy source is getting importance in thermal comfort of humans. Dehumidification is important parameter for thermal comfort where human beings live like homes, schools and offices. [2]

Green energy technology is best alternative to fossil fuels due to energy efficient and suitable for renewable energy resources [3]. The level of temperature and relative humidity is important for ideal human ease. Human beings need proper air-conditioning system for living which could fluctuate according to their needs and seasons. Air-conditioning system basically controls the temperature and relative humidity of ambient air. Today air-conditioning is essential for industrial air conditioning, agriculture products storage and nonhumans (animals) air-conditioning [4].[5]

In the air conditioner, sensible and latent loads should be controlled inside the buildings to create the indoor thermal comfort [6][8]. Mechanical based conventional vapor compression systems use the process of condensation of water vapors by controlling the latent load usually by cooling the air below the temperature of dew point then it can be reheated for required conditions [6].

With the increasing trend of population in Pakistan, demand of energy resources is increasing. Fossil fuels like coal and oil are main source of energy and their contribution toward energy production is about $87 \%$. But contribution of renewable resources is about $4 \%$. about $87 \%$ of total energy is produced from fossil fuels such as oil, coal, liquefied petroleum gas (LPG) and natural gas, while only $4 \%$ from renewable energy (RE) resources for total energy supply in the country.

The total energy produces from different sources during the fiscal year 2017 accounts for thermal as $64 \%$, followed by hydroelectric $26 \%$, nuclear $6 \%$ and renewable energy $4 \%$ illustrated in For energy saving point of view, DAC system can save $24 \%$ electrical energy and $1-13 \% \mathrm{CO}_{2}$ reduction when compared to other conventional system [9].

Table 1. Different climatic conditions for desiccant air conditioning system analysis reproduced from [10].

\begin{tabular}{llll}
\hline$\#$ & $\begin{array}{l}\text { Climatic } \\
\text { condition }\end{array}$ & T $\left({ }^{\circ} \mathbf{C}\right)$ & RH (\%) \\
\hline 1 & High humid & 23 & 90 \\
2 & $\begin{array}{l}\text { Moderate } \\
\text { humid }\end{array}$ & 28 & 70 \\
3 & Less humid & 33 & 50 \\
\hline
\end{tabular}

Desiccant has hygroscopic properties and creates vapor pressure difference in attraction of moisture. (DAC) controls humidity by dehumidification and temperature by evaporative. The DAC is the best technology because it does not use refrigerants like CFCs and HCFCs and required less energy for its regeneration process [11]. The size and dimensions of the DAC system depends on the supply air, ambient conditions, and source of heat for regeneration. Silica gel particles are used for adsorption purpose due to porous structure. They hold water in cavities presented in them. Solid desiccant systems could 
be best alternate of conventional systems [12], [13]. Fig.

1 shows the system schematics and the working process

of desiccant regeneration and dehumidification. After use,

air is again passed through heat source for regeneration.

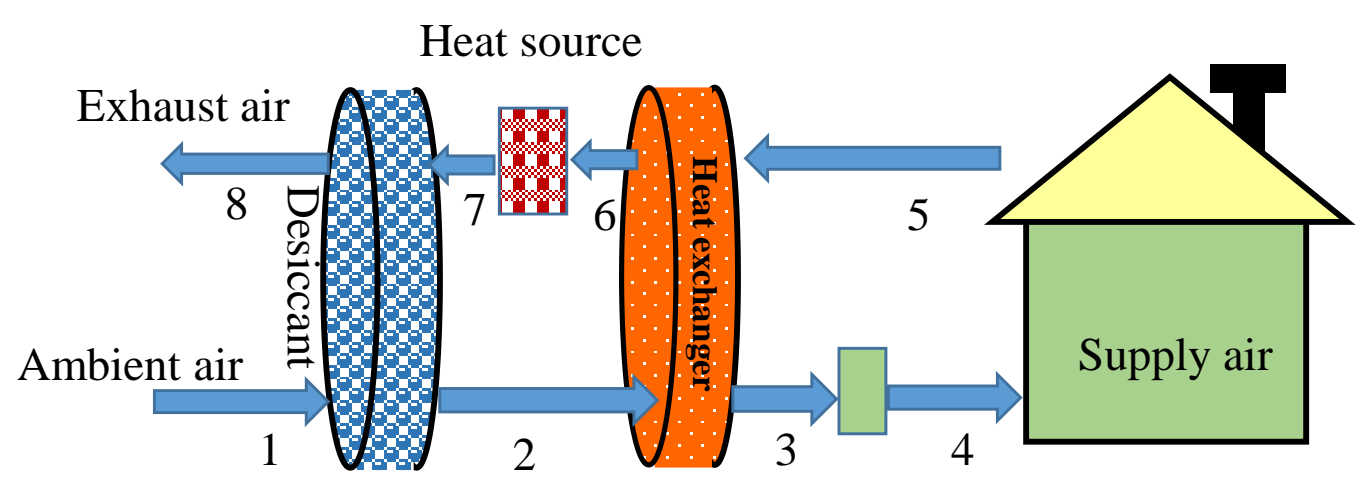

Fig 1. Schematic diagram of desiccant air -conditioning system.

The processing the air in heat exchanger, we can use it for required purpose. process is done continuously. Ambient air is first passed through desiccant wheel for dehumidification. Moisture in the air is adsorbs by desiccant wheel and gets dehumidified. After dehumidification, temperature of the air gets slightly higher [14]. Basically, desiccant wheel consists of desiccant material which adsorbs moisture from the air by developing pressure at desiccant surface and air vapor pressure. Vapor Surface get higher as air moves from point 1 to point 2 . It is the dehumidification process and after this process air is supplied to the required conditions. After the supply of air, regeneration process starts. Purpose of that process is to remove moisture from desiccant material by applying hot air at a temperature of about $50^{\circ} \mathrm{C}$. the whole process is shown in Fig. from point 6 to point 7 . After regeneration, the desiccant material is ready for next process of dehumidification and starts collecting moisture from the air [5], [15]. The regeneration is mandatory for the reactivation of silica gel for completion of cycle.

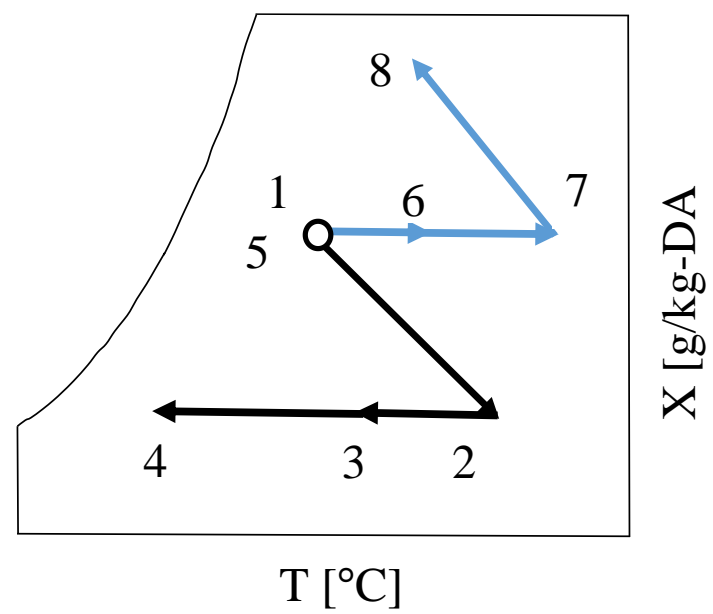

Fig 2. Psychrometric representation of working principle of DAC system.

For the desiccant cycle, the ratio of regeneration and dehumidification is considered as1:1. At this cycle ratio, process air get dehumidified up to $5 \mathrm{~g} / \mathrm{kg}$ [16]. The ideal DAC cycle was established on the psychrometric chart to attain the latent and sensible loads of air conditioning as shown in Fig. 2. Basically, the above-mentioned psychrometric chart shows the process of dehumidification and cooling process from point 1 to point 4 . Process of regeneration is from point 1 to point 8 and temperature is at increasing trend. With the increase of dry bulb temperature, numerical value of relative humidity decreases and vice versa. The values of humidity ratio decrease at the start of process of dehumidification and then it becomes constant from point 1 to point 4 at the psychrometric chart.

Working principle of desiccant dehumidification system is shown in Fig. 3. Air is passed through the desiccant block containing silica gel as desiccant material. Moisture in the ambient air is adsorbed and dry air with a relatively high temperature is obtained at the outlet of desiccant block. That dry cooled air is used for a specific application. For the continuous working of the system, regeneration process id helpful as it provides heat to remove moisture from the descant material and makes it suitable for next process.

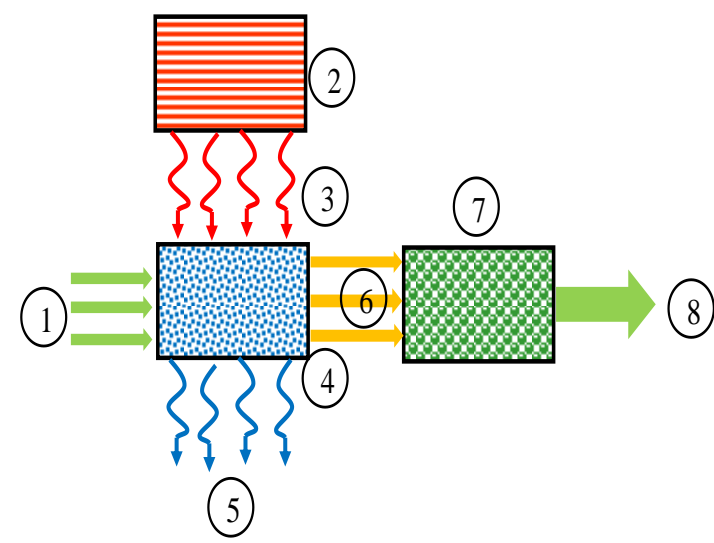

$1=$ Process air, $2=$ Regeneration heat source,
$3=$ Heat supply, $4=$ Desiccant dehumidifier
$5=$ Moisture out, $6=$ Dry air,
$7=$ Cooling unit, $8=$ Cooled supply air

Fig 3. Working principle of desiccant dehumidification system [17].

Desiccant material adsorbs water as it is hygroscopic. The adsorption phenomenon is shown in Fig. $4 \mathrm{~A}$ set of equations are used for the performance analysis of 
desiccant wheel and investigation of M-Cycle has been done which are developed by [18], [19]. The desiccant air conditioning system controls the sensible and latent load of air conditioning distinctly. Such distinct control of air makes the system more flexible for different application. The DAC system has been used in wide applications like agriculture product storage, livestock animals, green house air conditioning museums, hospitals, marines, automobiles. The potential of these application with DAC system have been discussed in the literature.

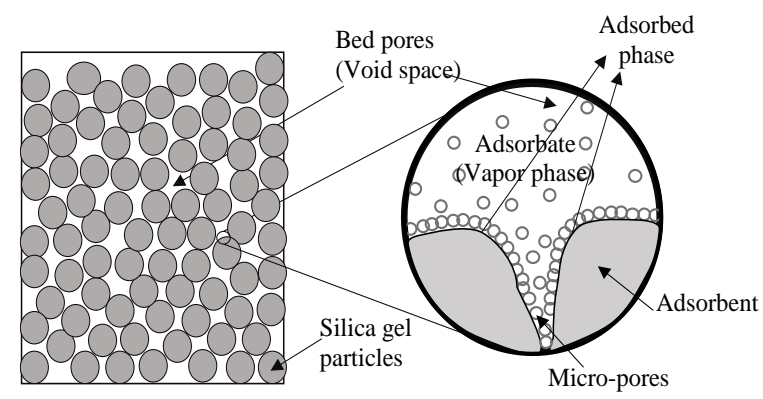

Fig 4. Water vapor adsorption phenomena in Silica gel.

\section{MATHEMATICAL FORMULATION}

To study the performance of desiccant air conditioning system, silica gel is used as desiccant material for performance analysis of desiccant wheel. The experimental system contains desiccant wheel for dehumidification, desiccant lock containing silica gel, heat source for regeneration of desiccant material.

Table 2. Conditions to operate the experiment

\begin{tabular}{lll}
\hline$\#$ & Parameters & Values \\
\hline 1 & Regeneration temperature & $50-70^{\circ} \mathrm{C}$ \\
2 & Ambient temperature & $35-400^{\circ} \mathrm{C}$ \\
3 & Humidity ratio of outdoor & $15-20 \mathrm{~g} / \mathrm{kg}$ \\
& air & \\
\hline
\end{tabular}

To compare the results mentioned above, Beccali model is applied for different climatic conditions like varying temperature and relative humidity. The silica-gel desiccant wheel (DW) based DAC system is considered in this study. [10], [20]. The measured data is obtained for silica gel performance evaluation. For this purpose, two kind of data are manipulated, temperature and relative humidity at inlet and outlet conditions. The restrained data is used in set of equations for performance analysis of silica gel. The equations have been used to measure the temperature, absolute humidity, and relative humidity for outlet conditions [18].

Performance evaluation of desiccant wheel is analyzed by using the set of equation from 1 to 4 .

Enthalpy from Beccali model is calculated using the equation 1 .

$$
\begin{aligned}
& h_{2}=0.1312 h_{7}+0.8688 h_{1} \\
& \mathrm{~h}_{7}=1.006 \mathrm{~T}_{7}+\mathrm{X}_{7}\left(2501+1.80 \mathrm{~T}_{7}\right) \\
& R H_{2}=0.9428 R H_{7}+0.0572 R H_{1} \\
& \frac{R H_{2} e^{0.053 T_{2}}-1.7976}{18671}=\frac{h_{2}-1.006 T_{2}}{2501-1.805 T_{2}} \\
& X_{2}=\frac{e^{0.053 T_{2}\left(0.9428 R H_{7}+0.0572 R H_{1}\right)}-1.7976}{18.671}
\end{aligned}
$$

Where $h_{1}$ and $h_{7}$ are enthalpies obtained from ambient conditions and regeneration process, respectively.
Relative humidity for Beccali model is calculated by using the equation 2 .

$\mathrm{RH}_{1}$ and $\mathrm{RH}_{7}$ are relative humidities at ambient conditions and regeneration process, respectively. $\mathrm{T}_{2}$ is outlet temperature for Beccali model. $\mathrm{X}_{2}$ is humidity ratio of outlet for Beccali model and is calculated by using the equation $4 . h_{7}$ is the enthalpy at regeneration process. The equation 1 and 2 are used to calculate the enthalpy and relative humidity at stage 2 which is the outlet of desiccant wheel and equation 3 is used to calculate the temperature of the after dehumidification. Equation 4 is the relation to measure the humidity ratio after dehumidification of air. Humidity ratio is same at point $1,5,6,7$.

Performance of the DAC system is evaluated by the expression of cooling capacity of the system and heating input during regeneration of the system. Enthalpy is main parameter for evaluating the coefficient of performance of the system. Equations of simulated model have advantage over other systems due to their simplicity. The model is not complex but used for the performance analysis of different desiccant systems. These equations are helpful in solving in solving complicated experimental data.

\section{RESULTS AND DISCUSSION:}

In the first stage of investigation, the basic performance of the desiccant wheel was evaluated at the regeneration temperature of $70^{\circ} \mathrm{C}$. It can be concluded from the results that desiccant air conditioning system is best suitable for the applications where the air having low temperature and humidity is required. For more precise requirements of air conditioning, we use some equations like Beccali model. These types of equations can result better as compared to desiccant dehumidification unit. Low temperature and low humidity can be obtained from equation. After analysis it can be concluded that model system used in this study is better than experimental system. Air flow rate and temperature of regeneration effects greatly for performance analysis of the system.

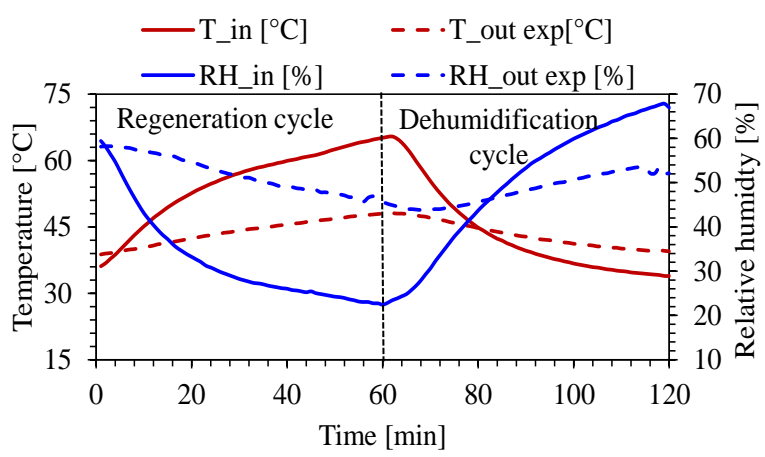

Fig 5. Performance evaluation of DAC system for temperature and relative humidity.

Fig. 1 represents the results obtained from the experiments of desiccant dehumidification system. At the outlet of the system, temperature gets slightly higher due to moisture adsorption at the desiccant material. When moisture adsorbs, air turned into dry form that cause in temperature increment. Inlet temperature range is $34^{\circ} \mathrm{C}$ and outlet temperature range is $40^{\circ} \mathrm{C}$. In case of relative 
humidity, it gets decrease at the outlet of the system due to moisture adsorption at the desiccant material. Moisture at the inlet point is $67 \%$ and moisture at outlet point is $52 \%$. Desiccant system is an attractive alternative due to properties of dehumidification [21]. Some analysis is done for ambient conditions to compare the results of desiccant dehumidification system by putting the values of ambient conditions. Outlet results are more feasible as compared to desiccant system. in other words, we can say that performance of the modeling system is better. For analysis, set of equations of Beccali's model are used. In this system, we measure the parameters of temperature, relative humidity, enthalpy, and humidity ratio.

Fig. 6 represents the overall performance of Beccali model results for temperature and relative humidity at the outlet points. Temperature at outlet condition is higher and relative humidity gets decrease as compared to inlet conditions.

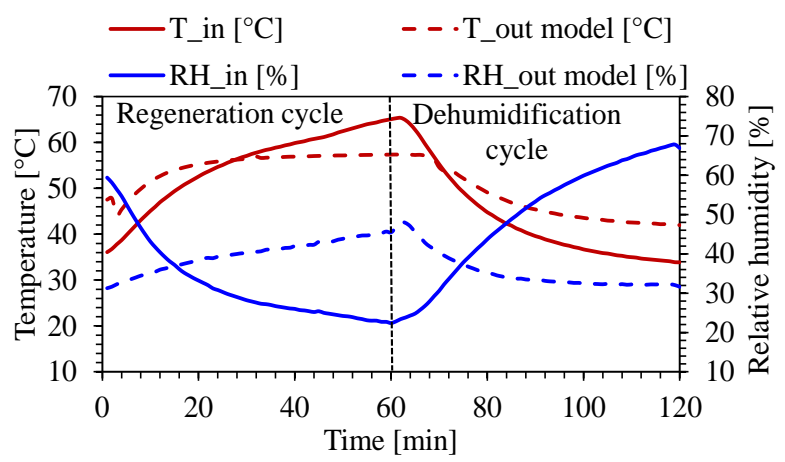

Fig 6. Performance evaluation of Beccali model for temperature and relative humidity.

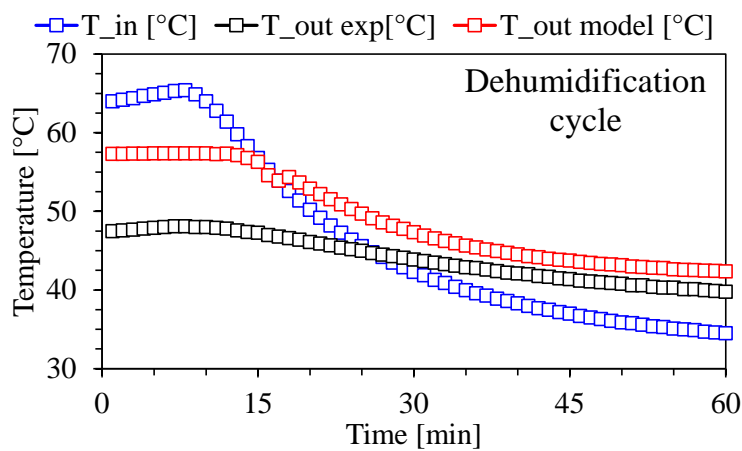

Fig 7. Comparison of temperature at inlet and outlet conditions of DAC system and Beccali model system.

Fig. 7 represent the performance of the experimental system and modeling system during dehumidification process. Experimental system of DAC achieves the temperature range $41^{\circ} \mathrm{C}$ to $48^{\circ} \mathrm{C}$ and in modeling system, the achievable temperature range $46^{\circ} \mathrm{C}$.to $58^{\circ} \mathrm{C}$ By performance evaluation of the both systems, we can conclude that performance of the modelling system is better as compared to experimental system. All the conditions are achieved within time limit. Therefore, the desiccant system is useful in the applications where the purpose is to just dehumidify the air.

Fig. 8 reveals that during the process of dehumidification, relative humidity at the outlet point is in decreasing trend as compared to inlet conditions of the systems. When compare the outlet conditions of the experimental system and Beccali model system then we can say that relative humidity at outlet condition of the Beccali model is less that is required. We can conclude that Beccali model is performing well toward feasibility of the system. The obtainable relative humidity range at outlet condition for Beccali model is $45 \%$ to $32 \%$ and from experimental system is $65 \%$ to $39 \%$ respectively. That is the reason behind the selection of Beccali model. Performance of the Beccali model is better as compared to experimental system of desiccant air conditioning system.

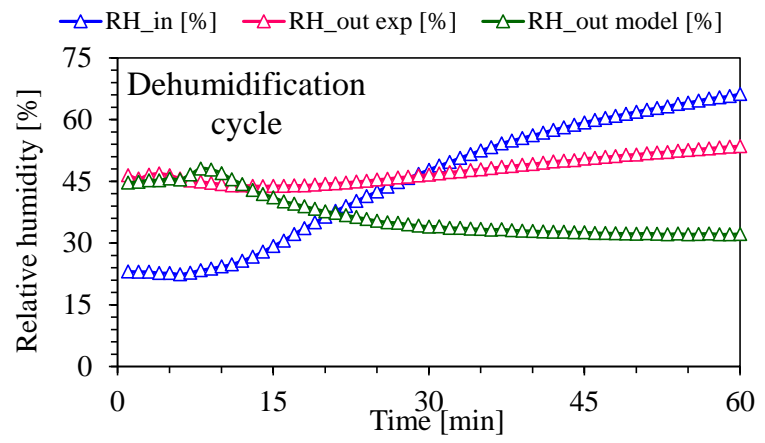

Fig 8. Comparison of relative humidity at inlet and outlet conditions of DAC system and Beccali model system.

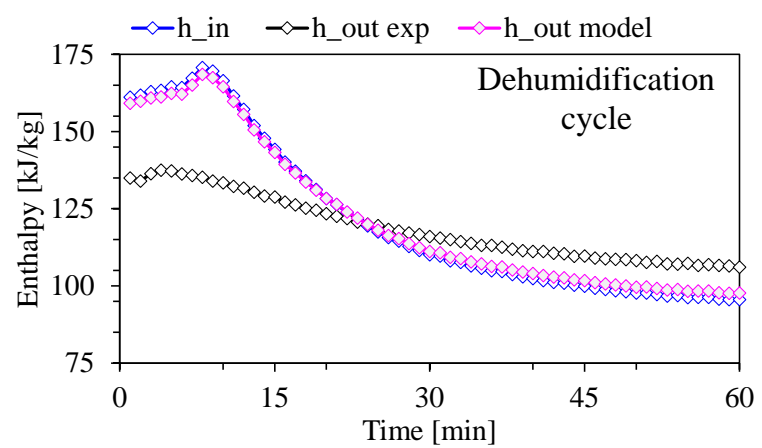

Fig 9. Enthalpy profile of outlet conditions of experimental system and Beccali model system.

Fig. 9 represents a difference between inlet and outlet conditions of both the compared system. Beccali model has low enthalpy approach as compared to experimental system. experimental system has more value of enthalpy which is not required for system feasibility. The enthalpy values show the performance of the two systems. Enthalpy for modelled and experimental system is almost same for throughout the dehumidification cycle. For performance point of view, we can conclude that Beccali model has accurate performance and is suitable for different applications.

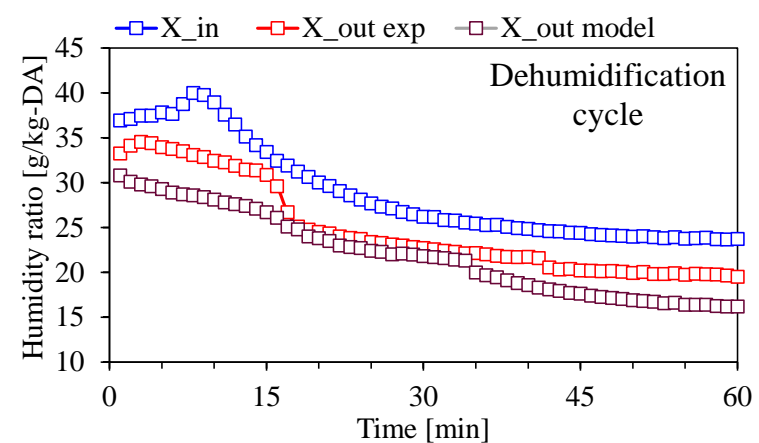

Fig 10. Dehumidification capacity of the experimental system and Beccali model system. 
Fig. 10 represents the moisture removal capacity of experimental system and Beccali model system. in this process comparison has been made. Model data is removing more moisture when compared with experimental data. Moisture removal capacity of model data is more than desiccant experimental system. The system is applicable in the applications of low humidity. Based on moisture removal or dehumidification capacity, the feasibility of the system is considered.

\section{CONCLUSIONS}

In Pakistan, dehumidification system is required in all humid areas and in rainy seasons during summer days. Less humid air is required in different air conditioning application. Pakistan has more potential toward renewable energy resources. It has been seen that desiccant dehumidification system is simple technology, but its performance is remarkable. If we combine its performance with some modelling system than the results are very attractive.

Present study experimentally investigates the performance of desiccant air conditioning system at different temperature and relative humidity. DAC can perform specific function at controlled system and need some modification in its performance based. for this purpose, set of equations of Beccali model are used for performance evaluation and the results are compared with DAC system. It is clear from the results that Beccali model performs better when compared to DAC system as it has more potential in dehumidification of air. Optimum value of temperature for regeneration purpose is $70^{\circ} \mathrm{C}$. regeneration temperature varies according to the applications like agriculture products storage, human thermal comfort, and animal air conditioning. A considerable working range is achieved by using the modelling system.

\section{Acknowledgements}

This research work has been carried out in the Department of Agricultural Engineering, Bahauddin Zakariya University, Multan-Pakistan. This research was funded by Bahauddin Zakariya University, MultanPakistan under the Director Research/ ORIC grant titled "Thermodynamic evaluation of low-cost airconditioning systems for various applications" awarded to Principal Investigator: Dr. Muhammad Sultan.

\section{Conflict of interest}

The authors declare no conflict of interest.

\section{REFERENCES}

[1] M. Kashif, M. Sultan, and Z. M. Khan,

"Alternative Air-Conditioning Options for Developing Countries," Eur. J. Eng. Res. Sci., vol. 2 , no. 1 , p. 76 , 2017, doi:

10.24018/ejers.2017.2.1.261.

[2] M. Sultan and T. Miyazaki, "SOLAR ASSISTED EVAPORATIVE COOLING BASED PASSIVE AIR-CONDITIONING SYSTEM FOR AGRICULTURAL AND LIVESTOCK APPLICATIONS," vol. 13, no. 3, pp. 693-703, 2018.

[3] G. Goodarzia, N. Thirukonda, S. Heidari, and A. Akbarzadeh, "Performance evaluation of solid desiccant wheel regenerated by waste heat or renewable energy," Energy Procedia, vol. 110, no. December 2016, pp. 434-439, 2017, doi: 10.1016/j.egypro.2017.03.165.

[4] M. Sultan, I. I. El-sharkawy, T. Miyazaki, B. Baran, and S. Koyama, "An overview of solid desiccant dehumidi fi cation and air conditioning systems," Renew. Sustain. Energy Rev., vol. 46, pp. 16-29, 2015, doi: 10.1016/j.rser.2015.02.038.

[5] S. K. Shazia Hanif, Muhammad Sultan, Takahiko Miyazaki, "Effect of drying air parameters on energy consumption in desiccant grain drying," 3rd Int. Exch. Innov. Conf. Eng. Sci., vol. 3, pp. 131-134, 2017.

[6] M. Mujahid Rafique, P. Gandhidasan, S. Rehman, and L. M. Al-Hadhrami, "A review on desiccant based evaporative cooling systems," Renew. Sustain. Energy Rev., vol. 45, pp. 145159, 2015, doi: 10.1016/j.rser.2015.01.051.

[7] H. P. D. A. Hindoliya, "Solid Desiccant Cooling System Employed with Ventilation Cycle : A Sensitivity Analysis," vol. 93, no. December, pp. 351-356, 2012, doi: 10.1007/s40032-0120038-9.

[8] M. Sultan, T. Miyazaki, M. H. Mahmood, and Z. M. Khan, "Solar assisted evaporative cooling based passive air-conditioning system for agricultural and livestock applications," J. Eng. Sci. Technol., vol. 13, no. 3, pp. 693-703, 2018.

[9] M. H. Mahmood, M. Sultan, and T. Miyazaki, "Solid desiccant dehumidification-based airconditioning system for agricultural storage application : Theory and experiments," vol. 0, no. 0, pp. 1-14, 2019, doi: 10.1177/0957650919869503.

[10] M. H. Mahmood, M. Sultan, T. Miyazaki, and S. Koyama, "Desiccant Air-Conditioning System for Storage of Fruits and Vegetables : Pakistan Preview," vol. 03, no. 01, pp. 12-17, 2016.

[11] G. Panaras, E. Mathioulakis, and V. Belessiotis, "Solid desiccant air-conditioning systems Design parameters," Energy, vol. 36, no. 5, pp. 2399-2406, 2011, doi: 10.1016/j.energy.2011.01.022.

[12] B. M. Ebarkì, İ. Solmuş, and R. G. Omrİ, “THE PERFORMANCE ANALYSIS OF A SILICA GEL / WATER ADSORPTION CHILLER AND DYNAMIC HEAT AND MASS TRANSFER CHARACTERISTICS OF ITS ADSORBENT BED : A PARAMETRIC STUDY ADSORPSIYONLU SILIKKA JEL / SU SOĞUTMA SISTEMININ PERFORMANS ANALIZİ VE ADSORBAN YATAĞININ DINA," pp. 107-118, 2016.

[13] S. K. Muhammad H. Mahmood, Muhammad Sultan, Takahiko Miyazaki, "Study on desiccant air-conditioning system for agricultural product storage in Pakistan," in Intellectual Exchange and Innovation Conference on Engineering \& Sciences (IEICES), 2015, vol. 1, pp. 13-14, doi: 10.1145/3132847.3132886.

[14] R. C. Resources, "S23 SI - Desiccant Dehumidification and Pressure-Drying 
Equipment (TC 8.12, Desiccant

Dehumidification Equipment and

Components)," 2008.

[15] S. Hanif, M. Sultan, T. Miyazaki, and S. Koyama, "Investigation of energy-efficient solid desiccant system for wheat drying," vol. 12 , no. 1 , pp. 221-228, 2019, doi: 10.25165/j.ijabe.20191201.3854.

[16] M. H. Mahmood, M. Sultan, T. Miyazaki, and S. Koyama, "Theoretical and Experimental Analysis of Desiccant Air Conditioning System for the Storage of Agricultural Products," pp. 110 .

[17] K. Daou, R. Z. Wang, and Z. Z. Xia, "Desiccant cooling air conditioning : a review," vol. 10, pp. 55-77, 2006, doi: 10.1016/j.rser.2004.09.010.

[18] M. Beccali, F. Butera, R. Guanella, and R. S. Adhikari, "Simplified models for the performance evaluation of desiccant wheel dehumidification," vol. 29, no. March 2002, pp. 17-29, 2003, doi: 10.1002/er.856.

[19] M. Sultan et al., "Thermodynamic assessment of solar chimney based air-conditioning system for agricultural and livestock applications," InProceedings 4th Int. Conf. Energy Environ. Sustain. Dev. (EESD, 2016), vol. 2016, no. Eesd, pp. 1-9, 2016.

[20] M. H. Mahmood and M. Sultan, "Significance of Temperature and Humidity Control for Agricultural Products Storage :," no. September, 2019, doi: 10.1515/ijfe-2019-0063.

[21] P. Mazzei, F. Minichiello, and D. Palma, "HVAC dehumidification systems for thermal comfort : a critical review," vol. 25, pp. 677707, 2005, doi:

10.1016/j.applthermaleng.2004.07.014. 